\title{
JABAR MASAGI: PENGUATAN KARAKTER BAGI GENERASI MILENIAL BERBASIS KEARIFAN LOKAL
}

\author{
Agus Suherman \\ DPBS FPBS Universitas Pendidikan Indonesia \\ Pos-el: agus.suherman@upi.edu
}

\begin{abstract}
Abstrak
Jabar Masagi merupakan salah satu program pemerintah Provinsi Jawa Barat periode 2018 - 2023 dengan oreintasi pada pendidikan karakter. Sasaran program ini terutama generasi muda atau kaum milenial. Dengan menggunakan metode deskriptif, tulisan ini mengupas landasan program tersebut disertai dengan uraian nilai kearifan lokal yang terkandung di dalamnya. Hasilnya, keterkaitan antara program Jabar Masagi dengan nilai kearifan lokal Sunda di antaranya terlihat dari rincian program yang sangat erat kaitanya dengan pandangan hidup, moto, dan ungkapan-ungkapan tradisional Sunda. Oleh sebab itu, pencanangan program ini selain merupakan acuan praktis dalam berperilaku, sekaligus merupakan reaktualisasi nilai-nilai kesundaan yang telah lama dianut. Melalui program gerakan yang dimotori oleh pemerintah daerah, semangat pemahaman dan pengamalan kembali terhadap nilai-nilai kesundaan dapat digelorakan secara semarak dan lebih kontekstual.
\end{abstract}

Kata kunci: Jabar masagi, kearifan lokal, generasi milenial.

\section{JABAR MASAGI: STRENGTHENING CHARACTERS FOR MILENIAL GENERATIONS BASED ON LOCAL WISDOM}

\begin{abstract}
Jabar Masagi is one of the government programs of West Java Province for the period 2018 - 2023 with a focus on character education. The target of this program is mainly the younger generation or millennials. By using descriptive methods, this paper examines the basis of the program along with a description of the value of local wisdom contained in it. As a result, the link between the West Java Masagi program and the value of Sundanese local wisdom can be seen from the details of the program that are closely related to the views of life, motto, and traditional Sundanese expressions. Therefore, the declaration of this program is not only a practical reference in behaving, it is also a re-actualization of the values of delay that have long been adopted. Through a movement program driven by the local government, the spirit of understanding and re-applying to the values of delay can be raised in a lively and more contextual manner.
\end{abstract}

Key Word: Jabar Masagi, local wisdom, millennial generation

\section{PENDAHULUAN}

Karuhun Sunda telah memiliki tradisi tersendiri untuk menata kehidupan, baik yang mengatur hubungan antara manusia dengan manusia, manusia dengan alam, maupun hubungan manusia dengan Tuhan. Aturan penataan tersebut ada yang tercatat dalam tradisi tulis, di antaranya dalam naskah kuno Sanghyang Siksakandang Karesian (SSK) yang ditulis tahun 1518 (Danasasmita, 1987:5), banyak pula yang tersebar dalam ingatan kolektif masyarakat berupa ungkapan lisan. 
Penataan yang dilakukan leluhur Sunda tersebut hampir menyentuh seluruh sektor kehidupan, mulai dari pendidikan, keagamaan, pemerintahan, kemasyarakatan, hukum, lingkungan, kesenian, dan yang lainnya, seperi tertera pada naskah SSKK. Maka tidak berlebihan jika naskah tersebut dianggap sebagai pedoman moral pada jamannya.

Petunjuk perilaku yang tergambar dalam naskah SSK bahkan telah diformulasikan dalam ungkapan bilangan klitik dan simbol yang mudah diingat, misalnya catur yogya (empat hal yang terpuji) yaitu: emas, jujur dalam perkataan dan tidak berbohong; perak, hidup tentram dan bahagia; permata, hidup tenang dan lapang; intan, murah senyum dan baik hati. Naskah SSK pun mengingatkan agar senantiasa waspada dan menjauhi pancagati (lima penyakit) yaitu keserakahan, kebodohan, kejahatan, kesombongan, dan keangkuhan.

Berkaitan dengan tugas manusia, naskah SSK menyebut sadguna, yaitu enam kegunaan, meliputi nyangka (citacita), nyigi (untaian), ngiket (mengikat), nyigeung (membagi/menyamakan), ngaruang (menggali), dan ngarombong (membatasi).

$$
\text { Adapun cara mencapai }
$$

kesejahteraan dan agar terhindar dari dosa dan celaka, SSK mengamanatkan dasa kreta, yaitu sepuluh kesejahteraan yang dicapai karena mampu menjaga sepuluh sumber nafsu, yaitu: teling $a_{s}$ jangan mendengarkan yang tidak layak didengarkan karena menjadi pintu bencana, penyebab celaka di dasar kenistaan neraka; mata jangan sembarang melihat yang tidak layak dipandang karena menjadi pintu bencana, penyebab celaka di dasar kenistaan neraka; kulit jangan digelisahkan karea panas ataupun dingin karena menjadi pintu bencana, penyebab celaka di dasar kenistaan neraka; lidah jangan salah kecap karena menjadi pintu bencana, penyebab celaka di dasar kenistaan neraka; hidung jangan salah mencium karena menjadi pintu bencana, penyebab celaka di dasar kenistaan neraka; mulut jangan sembarang bicara karena menjadi pintu bencana, penyebab celaka di dasar kenistaan neraka; tangan jangan sembarang mengambil karena menjadi pintu bencana, penyebab celaka di dasar kenistaan neraka; kaki jangan sembarang melangkah karena menjadi pintu bencana, penyebab celaka di dasar kenistaan neraka; tumbung (dubur) jangan dipakai "keter" (hubungan sejenis/homoseksual) karena menjadi pintu bencana, penyebab celaka di dasar kenistaan neraka; baga-purusa (kelamin perempuan - laki-laki) jangan dipakai berzinah karena menjadi pintu bencana, penyebab celaka di dasar kenistaan neraka.

Norma-norma lainnya yang tedapat dalam naskah SSK di antaranya catur yatna (empat kewaspadaan), catur utama (empat keutamaan), catur buta (empat hal yang mengerikan), panca tatagata (lima kenyataan), panca byapara (lima pelindung), panca gati (lima penyakit), panca parisuda (lima penawar), dasa sila (sepuluh larangan), dasa kalesa (sepuluh noda/dosa), dasa pasanta (sepuluh penenang hati), dan dasa prebakti (sepuluh pengabdian).

Berbagai pedoman perilaku yang mengatur sikap dan pebuatan tersebut tujuannya tiada lain untuk menciptakan ketertiban sosial dengan semaksimal mungkin menghindari perbuatan tercela. Itulah yang dicita-citakan sang darma, kesejatian hidup, manusia sempurna, $n u$ luhung elmuna, jembar budayana, pengkuh agamana, tur rancage gawena, nu teu unggut kalinduan tara gedag kaanginan.

\section{METODE}

Tulisan ini merupakan kajian kualitatif dengan menggunakan metode deskritif, yaitu mendeskripsikan nilainilai kearifan lokal yang berkaitan 
dengan program Jabar Masagi. Adapun teknik pengumpulan data dilakukan dengan studi pustaka, yaitu mengkaji sumber-sumber literat yang berkaitan dengan pandangan hidup, moto, dan ungkapan-ungkapan tradisional Sunda.

\section{HASIL DAN PEMBAHASAN}

Masagai berasal dari kata pasagi yang artinya "bentuk persegi", "segi empat" atau "bujur sangkar". Bentuk bangun seperti itu memiliki empat sisi yang sama dan seimbang. Oleh sebab itu benda yang memiliki bentuk demikian tidak pernah menggelinding atau bahkan tidak mudah goyah. Posisinya tegak kokoh karena ditopang oleh sudut atau siku-siku yang kuat. Metafor itulah rupanya yang hendak diterapkan terhadap warga Jawa Barat dari program Jabar Masagi, yaitu membentuk manusia Jawa Barat yang masagi. Jalma masagi yaitu manusia yang berpengetahuan atau serba tahu serta serba bisa (Satjadibrata, 2008:286). Oleh sebab itu jati dirinya tidak mudah terombang-ambing oleh pengaruh apapun, dan tentu saja hampir tidak memiliki kekurangan (euweuh cawadeun) serta mendekati sempurna atau bahkan sempurna. Lebih jauh Sudaryat (2015: 75) menyebutkan bahwa jalma masagi menggambarkan kualitas manusia Sunda yang beradab dan berkarakter, yaitu manusia yang nyantri "religius", nyunda "berbudaya", dan nyakola "akademis".

$$
\text { Jalma masagi memiliki }
$$

keseimbangan antara aspek jasmani dan rohani. Tubuhnya sehat jiwanya kuat. Manusia yang benar dalam bernalar, baik akhlaknya serta elok perilakunya. Ia adalah manusa manggapulia, insan kamil, atau dalam terminologi pembangunan nasional disebut sebagai manusia seutuhnya. Pembentukan karakter seperti itu tentu harus dilakukan secara menyeluruh dan seimbang, tidak hanya menekankan aspek material atau infrastruktur saja, melainkan juga unsur mental-spiritual. Itulah sebabnya program Jabar Masagi dihadirkan untuk mengimbangi pembangunan fisik yang semakin pesat dan meningkat.

Sasaran program ini terutama ditujukan kepada generasi muda atau kaum milenial, yang menurut Joel Stein (2013) dan Goldman Sachs (2016) adalah mereka yang lahir antara tahun 1980-an sampai 1990-an atau awal tahun 2000-an. $\mathrm{Hal}$ tersebut dapat dimengerti mengingat generasi ini memiliki sifat: (1) dari segi usia, generasi ini sangat produktif dan dinamis, sehingga memiliki kegairahan yang tinggi terhadap perubahan yang terjadi di lingkungannya; (2) generasi ini memilki literasi yang memadai di bidang teknologi, termasuk teknologi informasi, sehingga proses yang tengah berlangsung dan hasil yang telah dicapai dari program ini dapat dengan mudah disebarkan kepada anggota masyarakat lainnya; (3) generasi ini pun memiliki kebanggaan dan sekaligus kerinduan yang meggelora terhadap warisan budaya, sehingga program Rebo Nyunda di Kota Bandung misalnya, dapat disambut dengan berbagai kreasi seni dan budaya, misalnya pakaian daerah, bahasa daerah, revitalisasi seni tradisi (karinding), termasuk kajian-kajian kesundaan.

Program Jabar Masagi tentu saja sangat bersesuaian dengan spirit generasi ini, sekaligus memberi gagasan baru kepada mereka untuk kembali mengartikulasikan nilai-nilai kesundaaan dalam kehidupan sehari-hari. Melalui program ini generasi milenial Sunda diasah jiwa raganya untuk belajar "merasakan" (surti/rasa), belajar "memahami" (harti/karsa), belajar "melakukan" (bukti), dan belajar "mengabdi" (bakti/dumadi nyata).

Belajar surti atau "merasakan" adalah kesanggupan hati untuk menanggapi berbagai fenomena yang terindra, sehingga muncul pemahaman dan kesadaran atas dasar kelembutan hati dan perasaan. Pribadi yang surti di 
antaranya peka terhadap lingkungan sekitar, karena memiliki perasaan yang kuat untuk berempati. Sebuah ungkapan verbal atau bentuk penderitaan akan mudah menstimulan relung hati yang paling dalam, kemudian diikuti oleh tindakan yang patut dilakukan. Itu terjadi karena surti telah tertanam, dan rasa telah terasah dengan tajam.

Belajar harti atau "memahami" adalah sebuah dorongan jiwa untuk mengetahui, mempelajari, dan memahami tentang berbagai hal, misalnya ilmu, teknologi, dan seni. Pribadi yang harti akan memiliki kecakapan untuk memikirkan atau melakukan berbagai hal. Pada pribadi yang demikian tidak akan terjadi kegagapan atau ketinggalan jaman, karena senantiasa membekali diri dengan ilmu pengetahuan yang terbarukan. Karena keterpahaman dan kecakapan itulah pribadi yang surti dengan sendirinya akan membentuk masyarakat yang literat.

Belajar bukti atau "melakukan" berarti berupaya untuk menciptakan sesuatu, baik yang baru maupun memperbaharui. Tahap ini merupakan pembuktian bahwa pribadi yang masagi mampu merealisasikan gagasangagasannya menjadi nyata, bukan sekedar kata-kata. Hasil cipta ini malah akan berbicara lebih banyak dibandingan katakata.

Belajar bakti/dumadi atau "mengabdi" adalah mempersembahkan karya bagi khalayak, terutama bagi bangsa dan negara. Hal yang didapatkan dengan melakukan bakti adalah ketentraman jiwa, karena kewajiban sebagai anggota masyarakat telah tertunaikan, yaitu dengan mempersembahkan yang terbaik. Melakukan bakti tentu saja dengan berbagai hal dan cara, bukan hanya materi, tetapi juga dengan pemikiranpemikiran. Kuncinya adalah semuanya dilakukan atas dasar keikhlasan dalam kerangka hidup bersama.
Keempat nilai tersebut merupakan hasil internalisasi dari nilainilai kesundaan yang telah lama dianut dan diamalkan oleh masyarakatnya, sehingga disebut sebagai kearifan lokal. Itulah sebabnya cukup beralasan jika program Jabar Masagi "tidak mencari atau mengada-ada, tetapi merevitalisasi dan mereaktualisasi nilai-nilai yang telah ada," karena landasan kulturalnya telah mengakar pada masyarakatnya.

tersebut masih tersimpan berupa pependeman, yang hanya bisa dibuka dengan menggunakan kunci rahasia pancacuriga, yaitu silib, sindir, simbul, siloka dan sasmita. Kunci itu umumnya hanya dipegang oleh orang-orang yang wawuh ka semuna, apal ka basana, rancage hatena, dan rancingeus rasana. Pemegang kunci ini relatif lebih siap menerima wangsit berupa pendidikan karakkter seperti yang diamanatkan dalam Jabar Masagi.

Pendidikan karakter yang ditujukan bagi generasi milenial ini didasarkan pada empat nilai dasar, yaitu nilai religius (iman), cerdas (ilmu), berkarakter (akhlak), serta fisik dan mental (sehat). Keempat nilai tersebut sejalan dengan yang diistilahkan oleh Suryalaga (2003: 788) sebagai catur jati diri insan, yaitu 1) pengkuh agamana, taat menjalankan syariat agama atas dasar iman dan taqwa; 2) luhung elmuna, menguasai ilmu pengetahuan, teknologi dan seni; 3) jembar budayana, memiliki jati diri dan teguh memegang budaya; serta 4) rancage gawena, kreatif dalam bekerja serta dapat menyesuaikan diri dengan perkembangan jaman.

Nilai-nilai yang dikembangkan dalam Jabar Masagi sangat bersesuaian dengan nilai-nilai yang bersumber dari empat pilar kebangsaan yaitu Pancasila: nilai religius, nilai kekeluargaan, nilai keselarasan, nilai kerakyatan, dan nilai keadilan; UUD 1945: nilai demokrasi, nilai kesamaan derajat, dan nilai ketaatan 
hukum; NKRI: nilai kesatuan wilayah, nilai pesatuan bangsa, dan nilai kemandirian; serta semboyan Bhineka Tungal Ika: nilai toleransi, nilai keadilan, dan nilai gotong royong.

$$
\text { Nilai religius dalam Jabar }
$$

Masagi sangat sesuai dengan nilai kebangsaan yang bersumber dari Pancasila. Nilai cerdas atau berilmu sesuai dengan nilai kebangsaan yang bersumber dari NKRI yaitu kemandirian. Nilai karakter (akhlak) sangat sesuai dengan keempat pilar nilai kebangsaan tersebut. Seluruh nilai terjiwai oleh karakter atau akhlak yang baik. Nilai sehat fisik dan mental sesuai dengan nilai kebangsaan yang bersumber dari NKRI yaitu nilai kesatuan wilayah dan persatuan bangsa, serta akan mendukung dan mengokohkan terhadap nilai-nilai lainnya.

Inti dari nilai-nilai yang dikembangkan program Jabar Masagi akan bermuara pada jati diri Sunda yaitu cageur, bageur, bener, pinter, dan singer.

Cageur artinya sehat, baik jasmani maupun rohani. Ini merupakan syarat awal dalam mengembangkan sumber daya manusia, yaitu terpenuhinya kesehatan setiap individu, lahir dan batinnya. Bageur artinya baik, terutama dalam pikiran, perkataan dan perbuatan (tekad, ucap, lampah). Manusia bageur secara etika adalah yang dapat membedakan mana yang baik dan yang buruk, serta dapat membandingkan, mempertimbankan, memilah, dan memilih antara keduanya, serta hanya melakukan yang "baik" saja.

Bener artinya benar, terutama dalam bernalar dan bertindak. Manusia bener secara logika adalah yang dapat membedakan mana yang benar dan yang salah, serta dapat membandingkan, mempertimbankan, memilah, dan memilih antara keduanya, serta hanya melakukan yang "benar" saja.
Pinter artinya pintar, menguasai ilmu dan teknologi disertai dengan keterampilan dan kebijaksanaan dalam menghadapi, mengatasi dan menyelesaikan berbagai persoalan. Singer artinya kerja kreatif, memiliki kecakapan untuk melakukan pekerjaan serta dapat menyelesaikan pekerjaan tersebut dengan cepat dan tepat tanpa menunggu perintah.

Lima karakter atau sering disebut sebagai gapura panca waluya (lima gerbang keselamatan) tersebut telah lama diajarkan dan diwariskan secara turun-temurun. Nilai-nilai yang terkandung di dalamnya masih sangat relevan dengan perkembangan jaman kekininan, walaupun tentu saja, pengamalan dan keberterimaan setiap generasi akan sedikit berbeda-beda, karena situasi dan jiwa jaman yang menyertainya pun berbeda pula.

Di era disrupsi atau era perubahan mendasar yang cenderung tercerabut dari akarnya bahkan memunculkan kekacauan, diperlukan individu-individu yang tidak terlalu senang berada di zona nyaman, tidak alergi terhadap perubahan, dan mampu melakukan inovasi atau menghasilkan yang terbarukan. Inilah pribadi yang mampu ngigelan jaman, hidup sesuai dengan jiwa jamannya. Bagi yang demikian, era disrupsi bukanlah ancaman, melainkan merupakan peluang, karena setiap masa ada tanda-tanda jaman yang dapat mendatangkan keberkahan.

Era disrupsi ditandai dengan lompatan teknologi di antaranya revolusi industri 4.0 yang menimbulkan peralihan beberapa aspek kehidupan dari yang semula dilakukan secara manual menjadi digital. Dengan sifat surti, perubahan demikian tidak menimbulkan gegar budaya apalagi terlepas dari jati diri (jati kasilih $k u$ junti), tetapi menjadi pribadi yang teguh karena telah terasah menjadi rancingeus rasa, lebih peka dari peka. Hal tesebut disertai pula dengan penguasaan ciri-ciri perubahan itu sendiri, yaitu menjadi harti terhadap 
digitalisasi atau literasi digital. Jadi, secepat apa pun penyebaran informasi yang di dalamnya terkandung hal-hal negatif seperti hoaks, ujaran kebencian, fitnah dan sejenisnya, tidaklah menggoyahkan keyakinan apalagi ikut menyebarkannya. Hal tersebut karena surti dan harti telah tertanam dan menyatu dalam pribadi yang demikian.

Tahap berikutnya malah peluang datang menjelang, karena bukti telah menjadi ciri sebagai pribadi yang pernah belajar "melakukan" atau berkarya-cipta. Era ini memberikan peluang menjadi lebih kreatif dalam berwirausaha, misalnya jual-beli daring (on line), termasuk juga penyebaran gagasangagasan dan nilai-nilai budaya lokal secara daring melalui media sosial. Jika demikian, maka setiap tekad, ucap, lampah (pikiran, perkataan, perbuatan) akan menyemaikan kebaikan bagi sesama. Itulah sebaik-baiknya bakti/dumadi yang dipersembahkan, yaitu mampu memberikan sesuatu yang terbaik bagi lingkungan sekitarnya.

Nilai-nilai dasar yang terkandung dalam gapura panca waluya atau Jabar Masagi memang tidaklah turun dari langit atau datang dari ruang hampa, tetapi hasil dari dialektik akademik yang berlangsung terus-menerus. Oleh sebab itu pelaksanaannya pun harus dilakukan secara interaksional antar anggota masyarakat melalui pengamalan asas trisilas, yaitu silih asah, saling mengajari, silih asih, saling menyayangi, dan silih asuh, saling membimbing.

Melalui interaksi silih asah $k u$ pangabisa, silih asih ku pangarti, dan silih asuh ku pangaweruh akan tercipta dialog kebatinan antar anggota masyarakat dalam mewujudkan pribadipribadi yang taat agama, bela negara, cinta budaya, dan peduli lingkungan.

\section{SIMPULAN}

$$
\text { Program Jabar Masagi }
$$

memberikan kontribusi positif terhadap pendidikan karakter warga Jawa Barat terutama generasi milenial. Melalui program tersebut generasi muda dikenalkan sekaligus diakrabkan kembali terhadap dasar falsafah Sunda, yaitu cageur, bageur, bener, pinter, dan singer. Kelima jati diri Sunda tersebut teraktualisasikan dalam empat nilai dasar, yaitu nilai religius (iman), cerdas (ilmu), berkarakter (akhlak), serta fisik dan mental (sehat). Keempat nilai dasar tersebut diasumsikan mampu membentuk manusia Sunda yang luhung elmuna, jembar budayana, pengkuh agamana, dan rancage gawena. Hal tersebut ditempuh di antaranya melalui pembiasaan menjadi manusia yang surti, harti, bukti, dan bakti/dumadi. Keberhasilan program ini di samping tergantung kepada usaha membumikannya, juga dipengaruhi oleh kepekaan masyarakat Sunda terhadap pancacuriga yang diajarkan leluhurnya, karena nilai-nilai yang terkandung dalam program ini hanya dapat dipahami dan dilaksanakan oleh mereka yang wawuh ka semuna, apal ka basana, rancage hatena dan rancingeus rasana.

\section{PUSTAKA RUJUKAN}

Danasasmita, S. dkk. (1987). Sewaka Darma, Sanghyang Siksakandang Karesian, Amanat Galunggung. Bandung: Proyek Penelitian dan Pengkajian Kebudayaan Sunda (Sundanologi).

Sachs, G. (2016). Millenial Coming of Age. The Washington Post. Diakses 26 Desember 2018 dari https://www.washingtonpost.com/ sf/brand-connect/millenials/

Satjadibrata, R. (2005). Kamus Basa Sunda. Bandung: Kiblat Buku Utama.

Stein, J. (2013, 20 Mei). The Me Me Me Generation. Time, hlm. 30. Diakses 26 Desember 2018 dari https://www.time.com/247/milleni als-the-me-me-me-generation/ 
Sudaryat, Y. (2015). Wawasan Kesundaan. Bandung: JPBD FPBS UPI.

Suryalaga, H. (2003). Kasundaan. Bandung: Wahana Raksa Sunda.

Suryalaga, H. (2010). Filsafat Sunda. Bandung: Yayasan Nurhidayah.
UCAPAN TERIMA KASIH

Terima kasih kepada pengelola jurnal yang telah menerbitkan tulisan ini, serta kepada penulis terdahulu yang karya atau bukunya dikutip dalam tulisan ini. 